\title{
OS JUDEUS DE LEIRIA MEDIEVAL COMO AGENTES DINAMIZADORES DA ECONOMIA URBANA*
}

1. Fundação da judiaria $e$ sua topografia.

Muito embora sejam escassas as notícias sobre a presença de judeus na cidade de Leiria para o século XIII,é de crer que já existiria aqui uma pequena comunidade desde pelo menos inícios daquela centúria.

Objectivamente, encontramos num documento de Dezembro de 1219 a primeira referência a um judeu de Leiria, um tal Jucefe de Leirena, que surge a testemunhar uma venda efectuada por Regina Judea, suas filhas, e Salomão, filho de Almosarif, estantes em Lisboa, duma herdade que tinham em Vila Franca (c. Montemor-o-Velho; distr. Coimbra) ('). Isto não permite provar, na verdade, que já existia uma comuna em Leiria, sabido como é que o estabelecimento de judeus numa cidade se iniciava num contexto individualizado e singular. Só após a concentração dalgumas

* Principais abreviaturas: ANTT - Arquivo Nacional da Torre do Tombo; J P Séc. XIV-Maria josé Ferro, Os Judeus em Portugal no Séc.XIV, Lisboa,Guimarães Editores, 1979; JP Séc. XV-Maria José Ferro Ta vares, Os Judeus em Portugal no Séc. XV, Lisboa, Universidade Nova de Lisboa, 1980.

(') Arq. da Universidade de Coimbra-Cartulário de S. Paulo de Almaziva, fl. 18, doc. 58; publ. Maria José Azevedo Santos, O Cartulário do Mosteiro de S. Paulo de Almaziva, Edição Crítica, separata de Arquivo Coimbrão, vol. XXIX, Coimbra, 1981, doc. 85, pp. 132-133. 
famílias se passaria à instituição jurídica de comuna e ao levantamento de sinagoga $\left({ }^{2}\right)$.

A razão que nos leva a pensar que a judiaria já existiria naquele momento é de foro interpretativo histórico, resultando da leitura socio-topográfica do local onde se afirmará a comuna leiriense e, simultaneamente, da apreciação contextualizante do citado documento de 1219.

Como se sabe, Leiria foi fundada por D.Afonso Henriques em $\left.1135{ }^{3}\right)$, encabeçando a organização e exploração social e económica dum vasto território a sul de Coimbra. Ultrapassada uma fase inicial marcada pela insegurança e instabilidade que as razias muçulmanas provocavam, cerca de 1147, ano em que se conquistaram as cidades de Santarém e Lisboa, Leiria cresce demográfica e urbanisticamente, multiplicando-se as suas freguesias religiosas e provocando mesmo o estabelecimento dos frades menores por $1230\left({ }^{4}\right)$. Esta expansão atinge o auge em finais do século XII ou nos primeiros anos de Duzentos.

Esse crescimento populacional e urbano deve ter atraído as atenções dos judeus estabelecidos em cidades mais antigas como Coimbra. De facto, Leiria oferecia condições de enriquecimento muito favoráveis, pela disponibilidade de terras férteis, pelo baixo-custo duma mão-de-

(') Daniel Iancu-Agou, "Topographie des quartiers juifs en Provence médiévale", in Revue des études juives. Historia judaica, Paris, 1975, ed. Mouton, pp. 16-17.

$\left({ }^{3}\right)$ Sobre a fundação de Leiria por D. Afonso Henriques, vide Alexandre Herculano, História de Portugal desde o começo da monarquia até ofim do reinado de Afonso III, (prefácio e notas de José Mattoso), Lisboa, 1980,1.1, pp. 416-419, 603; Rui de Azevedo, "Período de formação territorial: expansão pela conquista e sua consolidação pelo povoamento. As terras doadas. Agentes colonizadores", in História da Expansão Portuguesa no Mundo, Lisboa, 1937, ed. Ática, pp. 37-39; Saul António Gomes, "A Mouraria de Leiria. Problemas Sobre a Presença Moura no Centro do País", in Estudos Orientais. II-O Legado Cultural de Judeus e Mouros, Lisboa, 1991, ed. Instituto Oriental - FCS - Univ. Nova de Lisboa, pp. 155-177, maxime p. 162, nota 14; Robert Durand, "Guerre et Fortification de l'Habitat au Portugal aux XII' et XIII Siècles", in Castrum 3. Guerre, Fortification et Habitat dans le Monde Méditerranéen au Moyen Âge, Madrid, 1988, Publ. de La Casa de Velázquez, Série Archéologique - fasc. XII, pp. 182-183.

( $)$ José Mattoso, "A cidade de Leiria na História medieval de Portugal", in Fragmentos de uma Composição Medieval, Lisboa, 1987, ed. Estampa, pp. 95-111; Luciano Coelho Cristino, "A vila de Leiria em 1385", in (Actas das) Jornadas Sobre Portugal Medieval. Leiria-1983, Leiria, 1986, ed. C. M. Leiria, pp. 171-220. 
-obra abundante, pelo mercado alimentar que se desenvolve em virtude do crescimento demográfico. Esta situação expressa-se logo no primeiro foral da cidade, outorgado em 1142, onde se estabeleceram cláusulas propiciatórias aos mercadores que quisessem abastecer o novo centro urbano de géneros alimentícios, particularmente vinho, carne e pão $\left(^{5}\right)$.

Neste contexto não causa estranheza que se tenham deslocado para Leiria algumas famílias judias pioneiras. Leiria terá sido, aliás, um dos novos centros que os judeus procuram numa ambiência de migrações dentro do reino português. $O$ próprio documento de 1219, atrás citado, parece indiciar um certo desinteresse por hebreus moradores em Lisboa de antigas propriedades detidas nas proximidades de Coimbra, herdadas dos seus antepassados, e que se tornavam porventura de difícil exploração, dada a distância que as separava dos seus proprietários.

Estes fluxos migratórios têm de inserir-se, cremos, no contexto expansionista global da sociedade cristã peninsular, muito embora seja pacífica a existência de comunas judias em territórios dominados pelos muçulmanos, casos de Lisboa e Santarém ( ${ }^{\circ}$ ). Mas isso não significa que a minoria judaica deixe de se integrar nos movimentos migratórios gerais das populações cristãs setentrionais em direcção aos espaços territoriais meridionais.

Em Leiria, a judiaria vai surgir num sítio que começou por ser marginal à urbe fortificada, evoluindo rapidamente, e sobretudo após 1150, para o estatuto de espaço charneiro entre duas freguesias cristãs. De facto, o local onde os judeus se estabeleceram era, na década de 1150, marginal à cidade, extra-muralhas, muito embora acompanhasse o caminho de acesso às Portas do Sol da povoação. Caminho que evoluirá para rua Direita. Por finais daquela centúria surgiu uma nova freguesia, com igreja matriz sediada um tanto a sul da judiaria, intitulada de S. Martinho,

(') Rui de Azevedo. Documentos Medievais Portugueses. Documentos Régios, vol. I, tomos I e II. Lisboa. 1958-1961, ed. Academia Portuguesa da História, doc. 189, pp. 233-235.

(') JP Séc. XIV, p. 12. 
cujos fregueses rapidamente envolvem o terreno destinado à população judaica.

A análise da planta da cidade indicia, de facto, estarmos perante uma área de urbanização tipo espinha de peixe, necessariamente controlada por um poder superior, orientador dos arruamentos e dos espaços de construção. Esse poder emanava necessariamente do rei. A este se deve atribuir, pois, a responsabilidade na autorização da fixação dos primeiros judeus junto das muralhas meridionais de Leiria ('). Com o crescimento urbano entretanto verificado, a judiaria acabou por ficar num local central da cidade extra-muralhas, justamente aquele que teria as características de espaço comercial e mercantil por excelência no burgo medieval $\left({ }^{8}\right)$.

A comuna leiriense deve ter crescido consideravelmente na primeira metade de Duzentos. Só assim me parece poder explicar-se o interesse pelos judeus dela em investirem na compra de terras ou na exploração de vinhas, como a que Aron Hebreu trazia no sítio das Mestas, nas imediações da cidade, antes de $1256\left({ }^{\circ}\right)$. O próprio interesse no investimento de produtos vinícolas poderá advir da necessidade de garantir aos judeus leirienses os vinhos próprios e consentidos na Lei mosaica $\left({ }^{10}\right)$.

Que a judiaria cresceu não há dúvidas, pois que os hebreus se vêem obrigados a emprazar casas de cristãos que passam a integrar-se no território comunal. Algumas eram adquiridas por judeus enriquecidos aos proprietários cristãos. É exemplo o contrato de 1293, no qual Isaac, rabi dos judeus de Leiria, sua mulher Ana, e Moisés, sobrinho de D. Ana

(') A localização de judiarias junto de muralhas era um facto frequente. Vide Daniel Iancu-Agou. op. cit., pp. 105-107.

$\left({ }^{8}\right)$ Saul António Gomes, "A Praça de S. Martinho de Leiria do Século XII à Reforma de 1546", in Mundo da Arte. II série. Janeiro-Março, pp. 57-78, Lisboa, 1990.

(') Arquivo Nacional da Torre do Tombo. Lisboa (= ANTT)-Mostelro de Alcobaça, l. $^{\text {ainc., }}{ }^{\circ}{ }^{\circ}$, n. $^{\circ} 4(\ldots$ 1256).

$\left({ }^{10}\right)$ Daniel Iancu-Agou. op. cit., p. 21 ("Enfin dans les propriétés foncières possédées par les Juifs, prépondérance est accordée à la vigne; cette préférence marquée pour le vignoble s'explique en partie pour des raisons d'orthodoxie. Le vin sert en effet à la célébration du qiddus. Le vin des producteurs non juifs était impropre à cet usage; aussi le vin Kaser devait-il être fabriqué et manipulé uniquement par les Juifs jusqu'à mise en fût"). 
renunciam a umas casas que haviam adquirido às herdeiras dum tal Fernando Afonso, "as quaes som na Juyaria de Leyrêa," em favor do mosteiro de Sta. Maria de Alcobaça ( $\left.{ }^{11}\right)$.

O desenvolvimento da comuna e das suas obrigações de sustento do culto religioso mosaico terá conduzido à aquisição do"0liual da juyaria", antes de $1306\left({ }^{12}\right)$. Esta propriedade deveria ser um referencial económico significativo, pois volta a ser assinalada numa carta de repartição de bens de 1308 como "erdade da juiaryaha con sseu Olyual". O mesmo documento refere ainda um outro "olyual e que foy de Martini saydo, que yas na Juiariha, con seu conchousso" $\left({ }^{13}\right)$.

Como se sabe, o azeite era um produto fundamental quer para a dieta alimentar dos hebreus, quer para as cerimónias religiosas. Não estranha, pois, a importância que o olival da comuna parece deter no tecido peri-urbano de Leiria $\left({ }^{14}\right)$.

Entre os diversos testemunhos da afirmação da identidade jurídica da comunidade encontra-se o "Conçelho dos judeus", existente em 1342, em cujas imediações laborava o tabelião cristão Afonso Domíngues ${ }^{15}$ ).

$O$ aumento da densidade habitacional judaica explicará as referências à "Rua da judaria", por 1337e 1361, a qual servia de ponto de referência para a identificação dos arruamentos envolventes onde Sta. Maria de Alcobaça e a Ordem de S. João do Hospital detinham prédios urba$\operatorname{nos}\left({ }^{16}\right)$.

Citemos mais um testemunho em favor do crescimento da judiaria, se bem que de 1373, mas que revela como o aluguer de casas na comuna era

(11) ANTT-Alcobaça. $1 .^{a}$ inc. m. ${ }^{\circ} 19$. n. ${ }^{\circ} 37$; id.. Dourados. 3, fls. 63 v ${ }^{\circ}-64$. n. ${ }^{\circ} 134$ (1293.IV. 17). Pub. por Pedro de Azevedo. "O trovador Martini Soarez e seu filho João Martins", in Revista Lusitana. n. ${ }^{\circ}$ 5. Lisboa. 1897-1899. pp. 114-136.

$\left(^{12}\right)$ ANTT - Alcobaça, $1 .^{\circ}$ inc.. m. ${ }^{\circ} 24$, n. ${ }^{\circ}$ 26; id. Dourados. 3. fl. 70 v. ${ }^{\circ}$, n. ${ }^{\circ} 153$ (1306.I.7).

(')Biblioteca Nacional de Lisboa-Reservados: Cód. 7.16. fls. 260-261 (1306.VI.30).

$\left({ }^{14}\right)$ Daniel Iancu-Agou. op. cit.. pp. 18-19.

$\left(^{\text {is }) ~ A N T T-A l c o b a c ̧ a . ~} 1 .^{\mathrm{a}}\right.$ inc, $\mathrm{m} .^{\circ} 31$, doc. 38 (1342.1.17).

$\left(^{16}\right)$ ANTT - Alcobaça. 2. ${ }^{\mathrm{a}}$ inc. m. ${ }^{\circ}$ 11. doc 253 (3), id.. Dourados, 3. fl. 82 v. ${ }^{\circ}$, n. 178 (1361.IV.22); id.. Sta Clara de Coimbra, cx. 1. séc. XIV, n. 7 (1337.VIII.23). 
lucrativo. Na verdade, por um documento daquele ano ficamos a saber que se praticava mesmo o sub-emprazamento entre cristãos relativamente a prédios ali situados. Estavam nesse caso as treze moradas de casas emprazadas pelo Hospital de D. Maria de Aboim, de Lisboa, a Estêvão Eanes Chichorro e sub-alugadas por este a treze famílias hebraicas $\left({ }^{17}\right)$.

Este crescimento da judiaria levou consequentemente à afirmação da sua singularidade e, de certo modo, à sua individualização como "ghetto", isto é, como espaço identificado e relativamente delimitado dentro do território urbano cristão. Em épocas de crise social, as tensões da maioria cristã são canalizadas contra a judiaria. Muito provavelmente na Páscoa de 1377, os fiéis cristãos de Leiria invadiram a comuna "britando as portas" e fazendo "mal e dapno nos corpos", perante a passividade das justiças locais $\left({ }^{18}\right)$. Em 1412, a judiaria tinha já portas para a Praça de $S$. Martinho $\left({ }^{19}\right)$. A delimitação física da judiaria acentua-se ao longo do século $\mathrm{XV}$.

Em 1455, o concelho leiriense solicitava autorização régia para que Mestre Belhamim, físico e cirurgião, vivesse fora da judiaria, "por lhes hij seer mujto neçesario por causa de seu ofiçio" $\left({ }^{20}\right)$. No mesmo ano, os procuradores do concelho pediam ao monarca que legislasse sobre a idade a partir da qual as moças cristãs só poderiam entrar na judiaria desde que acompanhadas por homem do mesmo credo $\left({ }^{21}\right)$. Em 1471, solicitava-se novamente a $D$. Afonso $V$ que autorizasse Mestre Abraão Abeatar, cirurgião e físico, a usar "hua porta que as ssuas cassas tijnham

(1) Arquivo Histórico da Câmara Municipal de Lisboa - Livro $1 .^{\circ}$ do Hospital de D. Maria de Aboim, fl. 6, doc. 4; ref.': Maria José P. Ferro Tavares, "Assistência Hospitalar em Lisboa", in A Pobreza e a Assistência aos Pobres na Península Ibérica durante a Idade Média. Actas das 1. Jornadas Luso-Espanholas de História Medieval, tomo I, Lisboa, ed. I. A. C., 1973. p. 393, nota 89.

$\left(^{18}\right)$ ANTT-Chanc. de D. Fernando, livro 3. fls. 26-26 v..$^{\circ}(1378.111 .26)$. Cf. Daniel Iancu-Agou, op. cit., pp. 109-111.

$\left(^{19}\right)$ ANTT-Sta. Clara de Coimbra. particulares. m. ${ }^{\circ} 11$. n. ${ }^{\circ}$.

$\left.{ }^{(20}\right)$ ANTT-Chanc. de D. Afonso $V$, 15 , fl. 62 v. ${ }^{\circ}(1455 . V I I .10)$.

${ }^{(1)}$ ANTT-Chanc. de D.Af ${ }^{o}{ }^{\circ}$. 15. fls.57-58; id.. Estremadura. VII, fls. 286v ${ }^{\circ}-288$ (1455. VI.26).Cf. Armindo de Sousa, As Cortes Medievais Portuguesas (1385-1490),Porto, ed. I.N.I.C.. 1990. vol. II. pp. 23. 348-354. 
contra a christandade", pois que "algüas vezes sse açertaua de noute o dicto mestre abrão sseer necesario por hijr curar d algüas pessoas E o nom podiam auer asi prestes como era necesario por morar dentro na dicta judaria" $\left({ }^{22}\right)$.

Estes documentos indiciam um efectivo isolamento arquitectónico da judiaria. Porventura não muito antigo, a avaliar pela tal porta que Mestre Abraão Abeatar tinha para a cristandade, muito embora selada. Em tempos passados, provavelmente, o problema não se poria.

Topograficamente, como vimos, o eixo essencial da judiaria era achamada rua da Judiaria. Já em 1337, e que fontes de inícios de Quatrocentos designarão também por rua da Lã dos Mercadores ou rua Nova $\left({ }^{23}\right)$.

Analisando alguns contratos de emprazamento de casas na zona judaica e respectivas confrontações, podemos definir com algum rigor a área ocupada pela comunidade minoritária.

Em 1361, o mosteiro de Sta. Maria de Alcobaça possuía casas "acima da Rua da Judaria" que partiam com José, judeu, duas outras ruas públicas e casas de S. João do Hospital $\left({ }^{24}\right)$. Estas casas da Ordem do Hospital voltam a ser referidas em documento de 1446 ("huas casas de morada (...) na dieta ujlla na calçada que uay pera o açogue da dieta ujla com seu lagar e logas e caualarjça e hu chãao que esta dentro na judaria que partem as casas e lagar e logas com Ruas prubjcas e com erança de mestre abrãao o uelho e com casas $d$ ordem do espritall e a caualariça parte com Rua que uem dos banhos pera as casas de fernamd afomso procurador e com casas de pichell judeu $\mathbf{E}$ o chãao que esta dentro na judaria parte com as dietas casas E com erança do dicto mestre abrãao" $\left.\left({ }^{25}\right)\right)$. Um outro diploma de

${ }^{(2)}$ ANTT - Chanc. D.Af ${ }^{\circ} V$, 16, fl. 4 v. ${ }^{\circ}(1471 . I .14)$.

$\left({ }^{23}\right)$ ANTT-Sta. Cruz de Coimbra. Livro 94. fl.285 (1399); id. Sta. Clara de Coimbra, particulares. m. ${ }^{\circ}$ 5. n. ${ }^{\circ} 27$ (1355.V.25); id., Ordem de Avis, $n^{o}$ 595, fl. 22 (1366.V.1); id., Alcobaça. Liv. ${ }^{\circ}$ 15, fl. 218 (1435). Cf. Saul António Gomes. "Leiria", in Atlas de Cidades Medievais Portuguesas (coord, por A.II. de Oliveira Marques, Iria Gonçalves e Amélia Aguiar Andrade), Lisboa. 1990. ed. INIC. pp. 51 -53.

$\left(^{24}\right)$ ANTT - Alcobaça. $2 .^{a}$ inc., m. ${ }^{\circ}$ 11. doc. 253 (3); id., Dourados. 3. fl. 82 v. ${ }^{\circ}$, n. ${ }^{\circ}$ 178(1361. IV.22).

$\left({ }^{25}\right)$ ANTT - Batalha. 4. n. 109 (1446.II.20). 
1449 refere-se a estas mesmas casas como situadas "na calçada que uay para a çerqua $E$ partem com duas ruas pruujcas e com ordem d ospytall e com rua da judaria" $\left({ }^{26}\right)$. Diploma de 1514 permite identificar esta "calçada" que levava as muralhas da vila com a Calçada de S. Pedro (actual rua Afonso Henriques), junto da qual ficavam as casas da Ordem de S. João $\left({ }^{27}\right)$. São, pois, os limites poentes da judiaria.

Os "banhos" referidos no texto de 1446 situavam-se no designado Largo dos Banhos, nome que permaneceria até à actualidade $\left({ }^{28}\right)$, portanto a nascente da judiaria. Nessa zona, embora voltada para a Praça de $\mathbf{S}$. Martinho, ficava a estalagem de Sta. Clara, a qual partia a norte com casas de Bento, judeu, por $1428\left({ }^{29}\right)$. Junto desta encontrava-se a "Porta da Judaria", voltada para S. Martinho, em $1412\left({ }^{30}\right)$. Desta Porta nascia a rua da Judiaria (hoje rua da Misericórdia) que cruzava com a rua Direita, seguindo em direcção à Calçada de $\mathrm{S}$. Pedro, via situada sobre uma mota e que parece não se ligava então com ela, como veio a suceder modernamente, através da construção das designadas "Escadinhas" (hoje rua Latino Coelho). Essa mota fazia terminar a Rua da Judiaria em beco. O citado documento de 1514 refere-o claramente ao indicar casas "na Rua do beco

$\left({ }^{26}\right)$ ANTT - Batalha. 4, n. ${ }^{\circ} 155$ (1449. VIII. 19).

${ }^{(27)}$ ANTT - Batalha, 1. fls. 57 v. ${ }^{\circ}-58$ (1514): "Item primeiramente na Rua do beco honde ffoy a judarja honde estaa hüua mota de cassas na Rua de ssam pedro (...)". Esta Calçada de S. Pedro, ou rua. será a citada nos dois documentos anteriores (notas 25 e 26) como Calçada da Cerca ou Calçada que leva ao Açougue. Ainda em documento de 1856 ("Relação dos enfiteutas do Hospital da Misericórdia de Leiria". na Bibl. Pública e Arquivo Distrital de Leiria, 19-I/9, doc. não numerado, fl. 12) se vêem referências a uma Rua das Alcaçarias("... Rua das Alcaçarias-que vai para o Arrabalde, antigamente denominada das Alcaçarias, próximo à Sé"), actualmente Rua de Pero Alvito. Sobre o significado de Alcaçárias vide J. Pinto Loureiro. "Enigmas da História de Coimbra", in Arquivo Coimbrão, vol.XII e vol. XIII. Coimbra, 1954e 1955. pp. 262-301 e 41-44. respectivamente.

$\left({ }^{28}\right)$ Saul António Gomes. "A Praça de S. Martinho de Leiria do Século XII à Reforma de 1546", in Mundo da Arte. II Série. Janeiro-Março. 1990. pp. 57-78.

$\left(^{29}\right)$ ANTT - Sta. Clara de Coimbra, cx. 4. séc. XV. n. ${ }^{\circ} 91$.

${ }^{\left({ }^{30}\right)}$ ANTT - Sta Clara de Coimbra, particulares,.$^{\circ}{ }^{11}$, n. $^{\circ} 2$.

$\left({ }^{31}\right)$ Este troço final cia antiga Rua da Juclaria é a rua hoje chamada Latino Coelho. Em 1912, chamava-se Ruadas Escadinhas (Arq. Distrital de Leiria-Conservatória Privativa da Comarca de Leiria. Ap. n. ${ }^{\circ}$ 1. de ll.XI.19J2, fls. 1-3). 
honde ffoy a judarja honde estaa huua mota de cassas" $\left({ }^{32}\right)$.

A rua Direi ta era designada, em 1447, por" Rua do terejro", em virtude de conduzir a este, cruzando a rua da Judiaria ("... casas e qujntall e poço e arvores em a dicta ujlla que som dentro na judaria na Rua do terejro $\mathrm{E}$ partem da huua parte com ssalamom mjuas (sic) judeu tjntorejro $\mathbf{E}$ da outra parte com jsaquee sauamell E com Rua proujca" $\left({ }^{33}\right)$ ).

A citada rua do Beco, em 1514, aparecerá igualmente referida como "beco do tereiro" por 1447 ('hü qujntall e poço...na judaria da dicta ujlla... o quall parte com casas da dieta ordem (Sta. Maria da Vitória) e com o dicto çadias e com salamam ujuas e com Rua da dieta judaria que estem no beco do tereiro" $\left({ }^{34}\right)$ ).

Torna-se relativamente fácil demarcar os limites setentrionais da judiaria, terminando junto do actual Largo da Sé, e onde deveriam existir portas. É bem mais difícil demarcar as fronteiras meridionais da comuna. Cremos não errar muito se propusermos como limites nesse ponto a rua do Godim (actual rua Gago Coutinho).

Globalmente, a área ocupada rondaria 1,5 ha, pouco mais ou menos. Istorepresentasensivelmente $5 \%$ do espaço global da cidade. A sua área, contudo, aproxima-se da da Judiaria Grande de Lisboa com 1,68 ha, supera a do bairro judaico de Évora com 1,24 ha e a da judiaria do Olival, no Porto, com 1,20 a 1,8 ha $\left({ }^{35}\right)$.

\section{Infra-estruturas urbanas.}

Entre as infra-estruturas urbanas da judiaria encontramos os banhos, situados na proximidade da sinagoga, a avaliar pela leitura da planta da cidade, aos quais conduzia uma rua paralela à da Judiaria ( $\left.{ }^{1}\right)$. A leitura arqueológica das estruturas ainda hoje existentes em torno da igreja da

$\left(^{32}\right)$ ANT T - Batalha. 1, fl. 57 v. ${ }^{\circ}(1514)$.

$\left(^{33}\right)$ ANT T - Batalha. 4. n. 154 (1447.V.2).

(34) AnTT - Batalha. 4. n. 60 (1447. V. 19).

${ }^{(35)}$ JP Séc. XV. pp. 52.63 e 69.

(') ANTT - Batalha, 4. n. 109 (1446.II.20). 


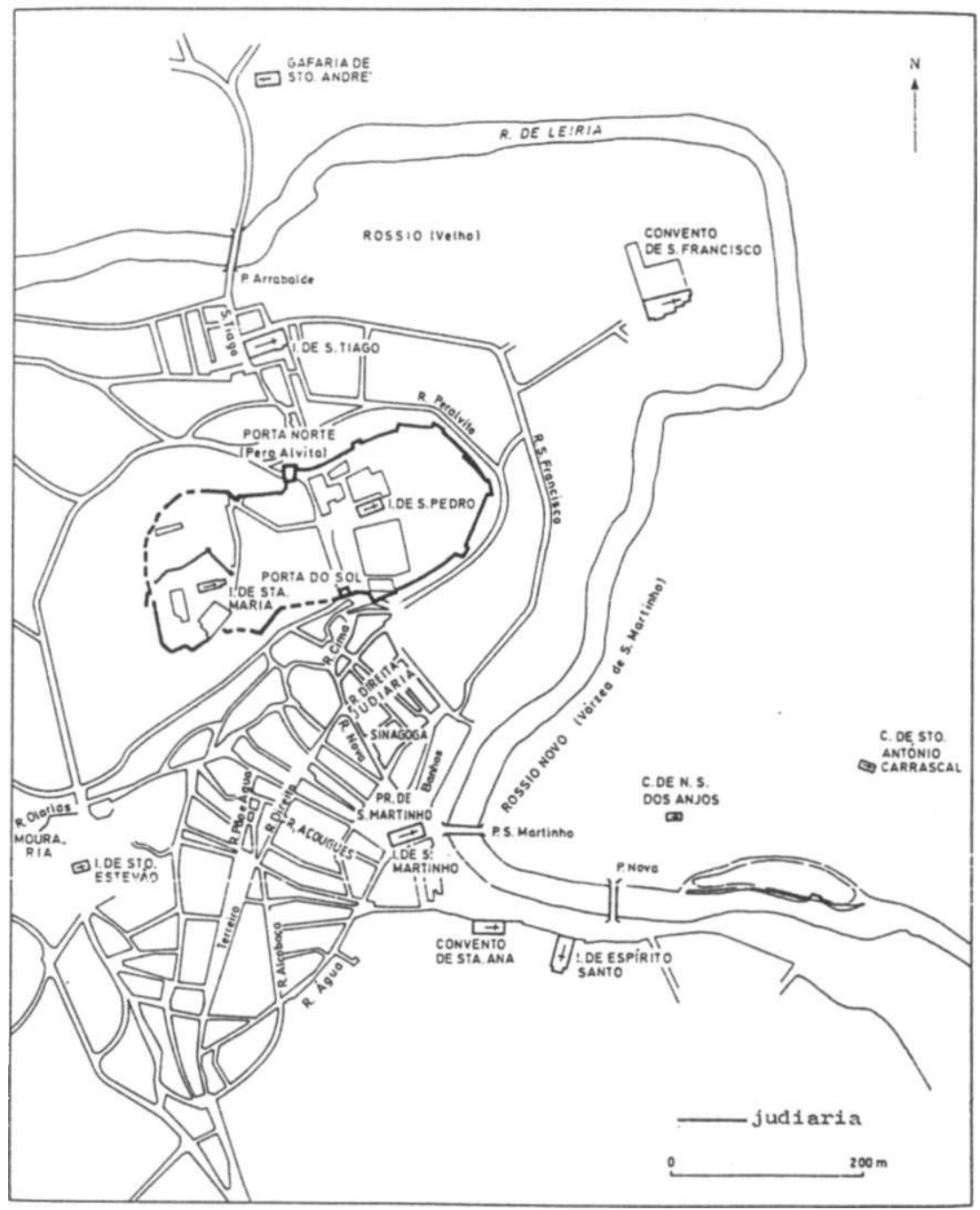


Misericórdia, que substituiu a sinagoga, indica a existência de alguns poços na área envolvente.

A documentação deixa pressupor a existência de tabernas e alcaçarias judaicas $\left({ }^{2}\right)$. Lagares para fabrico de vinho ou de azeite, bem como adegas aparecem documentados sempre como propriedade privada e não comunal $\left({ }^{3}\right)$. O mesmo acontece com cavalariças, estruturas indispensáveis a judeus mercadores, como fica bem demonstrado pelos privilégios obtidos do rei para que se pudessem deslocar em besta muar $\left({ }^{4}\right)$.

Junto da sinagoga estava muito provavelmente o Genesim, para o qual se cobravam 40 soldos por almude de vinho e 2 soldos por arrátel de cerveja, por 1393-94. Nesta altura. o levantamento do genesim fora arrematado por Santo, ferreiro, rendendo500 libras $\left({ }^{5}\right)$. Havendo Genesim onde os judeus se dedicavam exclusivamente ao estudo bíblico, será de pressupor a existência de uma escola elementar, o Beth Hamidrash, onde as crianças, e mesmo os adultos aprenderiam a ler, comentar e escrever a Lei mosaica $\left({ }^{6}\right)$.

Havia também "Concelho" da judiaria, não sendo impossível que se localizasse junto à sinagoga $\left({ }^{7}\right)$. Existia prisão dentro da judiaria. Dela sairia, por 1476, Moisés Tiboba "pela porta... que estaua aberta estando ho cacereyro presente" $\left({ }^{8}\right)$.

$O$ cemitério situava-se fora da cidade, junto à estrada para Cortes, a sudeste, o qual confrontava com olivais, estando "valado" em $1477\left(^{9}\right)$. En-

( ${ }^{2}$ ANTT -Alcobaça. 1. ${ }^{\mathrm{a}}$ inc., m. ${ }^{\circ}$ 19. n. ${ }^{\circ} 46$ (1394.VI.3); id., Chanc. de D. Af. ${ }^{o} \mathrm{~V}, 24$, fl.44(1443.XI.5);id..flafa//i«.4.n. ${ }^{\circ}$ 156(1449. VIII.9);id.,Ibidem, fl. 155(1449. VIII. 19).

$\left(^{3}\right)$ ANTT-Batalha. 4. n. 109 (1446.II.20);id.,ibidem, n..$^{\circ} 154$ (1447.V.2); id., ibidem, n. ${ }^{\circ} 173(1447 . V .19)$.

(') ANTT - Batalha. 4. n..$^{\circ} 109$ (1446.II.20); id., Chanc. D. Af..$^{o}$, 31, fl. 129 v. ${ }^{\circ}$ (1470.XII.13);29, fl. 81 (1471.I.8); 16. fl. 50 (1471.II.8); 16, fl. 57 (1471.III. 15); 16, fl. 141 v. $^{\circ}\left(1471\right.$. III.22); 33. fl. 29 v. ${ }^{\circ}(1472 . X I I .13) ; 33$, fl. 21 lv. ${ }^{\circ}(1473 . X I I .6)$; D. João II, 25. fl. 47 (1483.III.28).

(') ANTT-Alcobaça, $1 .^{\mathrm{a}}{ }^{\text {inc., }} \mathrm{m} .^{\circ}$ 19, n. ${ }^{\circ} 46$ (1394.VI.3); JPSéc XV, p. 166.

() JPSéc. $X V, p .34$.

(') ANTT-Alcobaça, 1. ${ }^{a}$ inc., m. ${ }^{\circ}$ 19, n..$^{\circ} 38$ (1342.I.17); JPSéc. XV, p. 45.

$\left.{ }^{8}\right)$ ANTT - Chanc. D. Af. ${ }^{\circ}$ V, 6, fl. 71 (1476.XI.5).

(') ANTT - Batalha. 4. n. ${ }^{\circ} 151$ (1477. V.24). 
contrava-se a uma distância da judiaria sensivelmente de um quilómetro.

Para lá das tendas dos mercadores de lanifícios, abundavam as lojas dos ferreiros, sapateiros, alfaiates, ourives e, em menor número, tintureiros, correeiros e latoeiros $\left({ }^{10}\right)$. A judiaria era um efectivo espaço de comércio e de produções manufacturadas.

\section{Personalidade jurídica da comuna e administração.}

Embora a judiaria se comportasse como um corpo social com personalidade jurídica desde praticamente o início do seu estabelecimento na cidade, a escassez da documentação a ela relativa implica que só em 1386 se encontre a primeira carta de privilégios atribuída à comunidade judaica. Neste ano, efectivamente, D. João I confirma-lhe " todos seus priuillegios foros liberdades e boons custumes de que sempre husarom" ( $\left.{ }^{1}\right)$.

Durante o reinado deste monarca (1385-1433),os judeus leirienses atravessaram um período de prosperidade e segurança. Em 1413, a comuna protestava contra o facto de Fernão Domingues, rendeiro da portagem de Leiria, não considerar os judeus ali moradores como Vizinhos do concelho. Alegavam também que o próprio D. João I lhes tinha outorgado um privilégio pelo qual eram escusados de pagar a dita portagem. Este efectivo privilégio dado à comuna contradizia, contudo, a Lei geral que proibia o estatuto de vizinho ao judeu, motivo que levou o rendeiro régio a actuar contra esse privilégio $\left({ }^{2}\right)$. A D. João I enviaria de novo a comuna de Leiria um procurador, Moisés Alguadixe, em 1431, protestando contra a quebra dos privilégios dos judeus mercadores da cidade em entrarem nas tabernas e estalagens de cristãos quando fora de Leiria, desde que não existissem comunas nessas outras terras que

$\left({ }^{10}\right) J P$ Séc. XV-II.pp. 174-179.

(') ANTT - Chanc. de D. João I,1, fl. 183 (1386.IV.14).

(') JP Séc. XV, pp. 397,447. nota I; Ordenações Afonsinas. II. t. ${ }^{\circ}$ LXVIIII, (Lisboa, ed. Fund. Calouste Gulbenkian. 1983. pp. 429-430). O documento em causa encontra-se no Arquivo Distrital do Porto - Cabido da Sé do Porto, Liv. ${ }^{\circ}$ 1673. fl. 2 (1414.V1II.8), 
percorriam tratando dos seus negócios. Este privilégio seria confirmado ainda naquele ano e ern $1450\left(^{3}\right)$.

A comuna veria reconhecidos os seus foros, graças, privilégios, liberdades e mercês por D. Duarte,em $1433\left({ }^{4}\right)$, regente D. Pedro, em 1441 $\left({ }^{5}\right)$, e D. Afonso V, em $1450\left({ }^{6}\right)$.

Em 1452, a comuna insurgia-se contra o peso excessivo dos judeus isentos de contribuírem para encargos comunais e públicos, autorizando o monarca que "oficiaees e homeens boons delia possam poer de ferros e escumunhõees e penas $E$ fazer todallas outras hordenaçõees que entenderem que sejom fectas por hordem de sua ley que per outra quallquer gujssa per que nehuu Judeu se nom escuse daqui en diante nem gaanhe carta nem priujllegios per que nom pague em as coussas sobredictas", anulando-se todos os privilégios e isenções concedidos, até então, nesse domínio (').

Em 1465, a comuna obteria privilégio geral, por intermédio de Vasco Martins Chichorro, do Conselho régio, para que não fossem tomadas as suas "bestas de ssella ou d albarda" para nenhumas cargas de peso, por parte do município $\left({ }^{8}\right)$.

Nem tudo eram isenções. Havia também obrigações a que a comuna não conseguia fugir. De facto, em 1476, D. Afonso $V$ determina que a judiaria dê aposentadoria à casa do conde de Vila Real, senhor de Almeida e donatário dos direitos reais em Leiria, do seu castelo e rendas dos judeus ( $\left.{ }^{9}\right)$.

tendo sido publicado por Humberto Baquero Moreno, "A sentença do rei D. João I contra os judeus, de 1412", in Revista Altitude, ano IV, 2." série, Guarda, 1984, n. ${ }^{\circ}$ 9-10, pp.49$-53$.

( ${ }^{3}$ A NT T - Chanc. D. Af. ${ }^{\circ}$ V, 34, fl. 153 (1450.III.5).

(') Id., Chanc. de D. Duarte, 1, fl. 20 (1433.XI).

(') Id., Chanc. D. Af. ${ }^{o} V$, 2, fl. 90 (1441.VI.5).

(') Id., Chanc. D. Af. ${ }^{o} V$, 34, fl. 59 (1450.V.7).

(') Id., ibidem, 3, fls. 58-58v. ${ }^{\circ}$ (1452.XII.3).

$\left.{ }^{8}\right)$ Id., ibidem, 38, fl. 64 (1465.I).

(') Id., ibidem, 1, fl. 39 v. ${ }^{\circ}$ (1476.VIII. 11). 
Em termos administrativos e judiciais, a comuna considerava-se coisa realenga. O rei era o seu senhor máximo para o qual se podia apelar em última instância. Antes, contudo, a correição da justiça hebraica passava pelo rabi-mor e pelos ouvidores deste, estando a comuna de Leiria integrada na comarca-ouvidoria de Santarém $\left({ }^{10}\right)$.Por 1470, encontrava-se em Leiria um tal Moussem Livym de Tomar,"ouujdor em a dicta comuna Dos judeus", recebendo queixas e denúncias (").

A alçada mais imediata da justiça comunal era detida pelo rabi local, que tomava conheci mento de todos os problemas de foro administrativo, judicial e penal relacionados com a comuna. Juda Alfaqui em 1475 "ouuera arroydo com hüu outro judeu e andamdo no dicto arroido acudiram outros seus procimos parentes e que o arrabij que entam era lhe posera assy a elle como aos outros degredo de certo tempo fora da villa e termo e pena çerta pera os captiuos", mandando "que esteuessem quedos e se metessem cada huu em sua casa sem seer ferjmdo nenhuu delles nem auendo de hy praantadas nem ferjdas algüuas nem soomente porem as mãaos huus nos outros" $\left({ }^{12}\right)$. O rabi tinha, como se vê, poderes suficientes para decretar degredos e multas pecuniárias.

Ao rabi de Leiria cumpria igualmente o julgamento de feitos da comunidade judia estabelecida em Porto de Mós. Em 1476, em virtude duma contenda movida entre diversos judeus daquela vila, a propósito da erecção duma sinagoga, foi ali "probricado huu aluara do araby de leiria", decidindo o pleito e recolhendo à "arca da cumuna" $\left({ }^{13}\right)$.

Aparentemente, apelava-se directamente para as justiças régias, porventura cristãs, o que implicava pesada multa $\left({ }^{14}\right)$. Em 1486, Salomão Almardom denuncia e querela de seu filho às justiças do rei, acusando-o do roubo de 12 mil reais $\left({ }^{15}\right)$.

$\left({ }^{10}\right)$ JP Séc. XV. p. 108.

(1) A N T T - Chanc. D. Af..$^{\circ}$ V. 26. fls. 47 v. ${ }^{\circ}-48$ (1481.Vin.2).

(12) Id., ibidem. 30. fl. 128 v. ${ }^{\circ}(1475 . I V .17)$.

$\left(^{13}\right)$ Id., Batalha. 4. n. ${ }^{\circ} 27$ v. ${ }^{\circ}(1476.1 .31)$.

$\left({ }^{14}\right) J P$ Séc. $X V$. p. 109.

$\left.{ }^{15}\right)$ ANTT-Chanc. D. João II. 1. fl. 30 (1486.II.15). 
Os ofícios de rabi, vereador e oficial da comuna eram encargos pouco desejados. Compreende-se bem que os privilegiados da comuna os procurassem evitar pedindo isenção deles ao rei. Conseguiram-na, em 1469, José Prateiro, ourives, $\left.{ }^{(16}\right)$, Salomão Amerdam, ourives $\left({ }^{(7)}\right)$, Moisés Levi $\left({ }^{18}\right)$, e na década de 1470, Joanas Abeatar $\left({ }^{19}\right)$.

Entre os ofícios que se registam para a comuna estavam também o de procurador, almotacé, taxador de pedidos, representante de "emprestados" e escrivão da câmara $\left({ }^{20}\right)$.

A comuna tinha também os seus tabeliães próprios ou, então, recorria aos tabeliães gerais dos judeus. Entre 1475 e 1483, conhece-se a permanência em Leiria de Juda Alfaqui, tabelião geral nas comunas do reino e especial na da cidade $\left({ }^{21}\right)$. Juda Barcelimi é tabelião aqui por 1482 $\left({ }^{22}\right)$, e Abrãao Franco é público tabelião da comuna por $1486\left({ }^{23}\right)$.

Havia ainda cárcere e respectivo guardião $\left({ }^{24}\right)$.

Não se encontram referências a outros cargos e oficiais próprios das comunidades mosaicas. É de admitir, no entanto, que existiriam inúmeros outros funcionários, conforme o costume desta minoria $\left({ }^{25}\right)$.

4. Vida económica e rendas da judiaria.

Os documentos mais antigos que se referem a judeus em Leiria indicam-nos que eram proprietários rurais, como Arão Hebreu, que possuía vinhedos antes de 1256 ( $\left.{ }^{(}\right)$, nos arredores da cidade, e Abrãao Ju-

${ }^{(1)}$ Id., Chanc. D. Af. ${ }^{\circ}$ V, 31, fl. 54 (1469.VI.15).

(1) Id., ibidem, 31, fl. 54 (1469.VI. 17).

${ }^{(18)}$ Id., ibidem, 16, fl. 97 (1471. V.3); 26. fls. 47 v. ${ }^{\circ}-48$ (1481.VIII.2).

(') Id., ibidem, 16, fl. 97 (1471.V.3); 26. fls. 47 v. ${ }^{\circ}-48$ (1481.VIII.2).

$\left.{ }^{(20}\right)$ Id., ibidem, 31. fl. 54 (1469.VI.17).

$\left.{ }^{(11}\right)$ Id., ibidem, 30. fl. 128 v. ${ }^{\circ}$; id., Chanc. D. João II, 24, fl. 31 v. ${ }^{\circ}$, JP Séc. XV, p. 178.

('2) A NTT-Chanc. D. João II. 2, fls. $90-90$ v. ${ }^{\circ}(1482 . I V .1)$.

$\left(^{23}\right)$ Id., ibidem, 1, fl. 30 (1486.II.15).

${ }^{(24)}$ Id., Chanc. D. Af. ${ }^{\circ}$ V, 6. fl. 71 (1476.XI.5).

$\left.{ }^{2 s}\right)$ JP Séc. XV. pp. 123-125.

(') ANTT -Alcobaça, $1 .^{\mathrm{a}}$ inc., $^{\mathrm{I}} .^{\circ} 12, \mathrm{n}^{\circ} 13(1256)$. 
deu, genro de D. Justa, com terras no Freixo, por $1306\left({ }^{2}\right)$. As propriedades poderiam ser consideravelmente ricas. Em 1312, por exemplo, Benjamim Coimbrão e sua mulher Citi venderam a um criado de D. Pedro Afonso Ribeiro dois casais junto a Ortigosa, por 250 libras $\left({ }^{3}\right)$. Encontramos novos testemunhos de judeus proprietários de terras situadas nas imediações do centro urbano. Assim sucedia, por exemplo, com um tal Bento Judeu, com um olival nas Quebradas, por $1360\left({ }^{4}\right)$.

A propriedade rural era também suficientemente apreciada para ser hipotecada a credores judeus. Por 1292, Daniel recebe 200 libras em razão duma penhora que detinha sobre as terras de Vicente Domingues Azar, no Vidigal $\left({ }^{5}\right)$. $O$ crédito judaico servia também à nobreza. Em 1326, um tal Benjamim, judeu de Leiria, recebia a "dívida de mayor quantia contrahida por Martini Afonso Pay de D. Aldonça Martinz Freira de Tarouquella que a satisfizerão por auynça com rebate" $\left({ }^{6}\right)$.

Interessava bastante, como se compreenderá, a posse de prédios urbanos. Isaac, rabi, e sua mulher Ana, com outros familiares, renunciam a favor do mosteiro de Sta. Maria de Alcobaça certas casas que traziam na comuna, sem que o documento de 1293 explicite pormenores $\left({ }^{7}\right)$. A valorização económica do espaço urbano justificava o interesse com que se recebe a doação dum pardieiro, em $1391\left({ }^{8}\right)$, ou se penhora a casa de Santo, judeu ferreiro, avaliada em 500 libras, em $1394\left({ }^{\circ}\right) .0$ arrendamento destes prédios permitia, ainda, frutuosos negócios em contratos de sublocação $\left({ }^{10}\right)$.

() Bibl. Nac. de Lisboa - Reservados, Cód. 736, fls. 260-261 (1306).

( ${ }^{3}$ A NT T-Sta. Clara de Coimbra, cx. 1, séc. XIV, não numerado (1312.IV. 11).

(') Id., Alcobaça, 2. ${ }^{a}$ inc., m. ${ }^{\circ}$ 12, n. ${ }^{\circ} 282$ (14) (1360.IX.4).

( $\left.{ }^{5}\right)$ Id., Alcobaça, $1 .^{\mathrm{a}}{ }^{\text {inc., }} \mathrm{m} .{ }^{\circ}$ 19, ${ }^{\circ}{ }^{\circ} 24$ (1292.IV.25).

(')Bib. Geral da Universidade de Coimbra-Manuscritos: Cód. 19,fl.98(1323.IV.6).

(') ANTT-Alcobaça, $1 .^{\mathrm{a}}$ inc. $\mathrm{m} .{ }^{\circ}{ }^{19}, \mathrm{n} .{ }^{\circ} 37$ (1293.IV.17).

$\left.{ }^{(}\right)$Id.. Estremadura, XI, fls. 67-67v. ${ }^{\circ}$; id., Chanc. de D. João I, 2, fl. 62 v. ${ }^{\circ}(1391$.XII.6).

(') Id., Alcobaça, 1. ${ }^{a}$ inc, m. ${ }^{\circ}$ 19, n. ${ }^{\circ} 46$ (1394.VI.3).

$\left(^{10}\right)$ Arq. Histórico da Câmara Municipal de Lisboa-Livro $l .^{\circ}$ do Hospital de D. Maria de Aboim, doc. 4 (1373.XI.9), e doc 20 (1406.IV.31); ref." Maria José Ferro P. Tavares, "Assistência Hospitalar em Lisboa", cit., p. 393, nota 89. 
As actividades comerciais e manufactureiras, com vista ao mercado local, contudo, eram proeminentes no quotidiano da comuna. $O$ elevado número de cartas de privilégios outorgados pelo rei aos mercadores e mesteirais, que comerciavam os seus próprios produtos, permitindo-lhes contratar por todo o reino, em pé de igualdade com os cristãos, tornaram-se muito abundantes ao longo de todo o século XV (").

Os mesteirais locais agem como pequenos comerciantes, contribuindo para activar um mercado regional. Em 1437, Moisés de Abrantes, Abrãao Baça, Isaque Tovi, Daniel e José, sapateiros, moradores em Leiria, compravam três tagras de coiros ao Mosteiro de Alcobaça $\left({ }^{12}\right)$. Por seu turno, este instituto comprava a Salomão Saçom, de Leiria, sabão "para a câmara de dom abade" ( 260 reais em 13.III. 1439) $\left({ }^{13}\right)$, e a Bento Saçom, da mesma cidade, panos brancos de lã de Castela (8 peças e 19 côvados em 6.XII. 1437, num total de 9714 reais $\left({ }^{14}\right)$, mais 10 peças entre aquela data e 7.II. 1438, num total de 11700 reais) $\left({ }^{15}\right)$.

Os grandes mercadores da comuna tinham as suas casas-armazéns nos portos marítimos próximos de Leiria. Era o caso do já citado Bento Saçom, com pousadas nas Paredes $\left({ }^{16}\right)$, por $1437 / 1438$. De facto, Paredes era um porto muito significativo para a região. Tanto quanto a Pederneira (hoje Nazaré), onde Samuel Abanazo, mercador em Leiria, trazia casas de Alcobaça, ampliando-as por 1486 ('). Por esses entrepostos comerciais se recebiam mercadorias de Castela e de Bruges na década de $1440\left({ }^{18}\right)$.

(")JP Séc. $X V$-II, pp. 174-179.

$\left(^{12}\right)$ ANTT - Alcobaça, Liv. ${ }^{\circ}$ 14, fl. 220 v ${ }^{\circ}$.

(') Id., ibidem. fl. 171.

( ${ }^{14}$ )Id., ibidem, fls. 134, $117 \mathrm{v} .{ }^{\circ}$ e $123 \mathrm{v} .{ }^{\circ}$.

$\left(^{15}\right)$ Id., ibidem. fls. 16v $.^{\circ}, 86,132$ v. ${ }^{\circ}$ Cf. Iria Gonçalves, O Património do Mosteiro de Alcobaça nos Séculos XIV e XV, Lisboa, ed. Universidade Nova de Lisboa, 1989, pp. 326-327; Ana Maria Pereira Ferreira. A Importação e o Comércio Têxtil em Portugal no Século XV(1385 a 1481), Lisboa, ed. INCM, 1983, pp. 107-130.

${ }^{16)}$ ANTT-Alcobaça, Liv. ${ }^{\circ} 14$, fls. 16-16v. ${ }^{\circ}, 17 \mathrm{v} .{ }^{\circ}$.

$\left(^{11}\right)$ Id., ibidem, Dourados, 1 , fls. $62 \mathrm{v} .^{\circ}-63$, n. ${ }^{\circ} 158$ (1486.VII.12).

$\left({ }^{18}\right)$ J. Veríssimo Serrão, Relações Históricas entre Portugal e a França (1430-1481), Paris, ed. Fund. Calouste Gulbenkian, col. "Memórias e Documentos para a História Luso-Francesa", XIII, 1975, pp. 38-39. 
Por eles, também, se exportavam madeiras do Pinhal de Leiria e papel fabricado na cidade do $\operatorname{Lis}\left({ }^{19}\right)$.

A presença regular das cortes régia e senhoriais (condes de Vila Real, prior-mor de Sta. Cruz de Coimbra, entre outras mais esporádicas) em Leiria, ou na região envolvente (condes de Ourém, neste concelho e em Porto de Mós; abade de Alcobaça) atraía mercadores e exigia mão-de-obra disponível para acudir às necessidades dessas mesmas casas. Alfaiates, sapateiros e ferreiros, em maior número, mas também ourives, físicos e cirurgiões, entre outros menos significativos.

Não admira que os próprios mesteirais e pequenos mercadores judeus tenham demandado outras sedes concelhias próximas da comuna leiriense, procurando mercados bem servidos de vias de comunicação que ligavam Lisboa, Santarém e Tomar, entre outras cidades estremenhas, a Leiria e Coimbra.

Dessa procura de novos entrepostos de comércio chegam-nos testemunhos em Aljubarrota, onde se instalava Isaac da Batalha e sua mulher Viziboa, por $1407\left({ }^{20}\right)$, em Porto de Mós, desde antes de $1428\left({ }^{21}\right)$, vila onde o comércio de coirama era de vulto e ocupava judeus $\left({ }^{22}\right)$, de Ourém, já antes de 1442, assim como na Pederneira e em Pombal $\left({ }^{23}\right)$.

Em todos estes pólos concelhios, bem servidos de linhas de comércio terrestre e marítimo, no caso da Pederneira, se estabeleceram judeus, na maior parte mesteirais (sapateiros, ferreiros, marceiros, tecelões, alfaiates.

(') ANTT-Alcobaça, Liv. ${ }^{\circ} 14$, fl. $17 \mathrm{v} .{ }^{\circ}(2$ resmas de papel compradas nas Paredes), Exportavam-se, de facto, via marítima, madeiras do Pinhal Real para Lisboa a partir dos portos da região. Entre estes era principal o da Pederneira. Em 1501, por exemplo, o Mosteiro da Batalha trazia ali uma caravela para transporte daquela mercadoria (ANTT - Chanc. D. Manuel I, 17, fl. $102 \mathrm{v}^{\circ}$ ). Sobre este porto da Pederneira (hoje Nazaré) ver Laranjo Coelho, "A Pederneira - Apontamentos para a história dos seus mareantes, pescadores, calafates e das suas construções navais nos séculos XV a XVIII", in $O$ Archeologo Português, Lisboa, vol. XXV, 1924, pp. 196-247.

$\left(^{20}\right.$ ANTT-Alcobaça, Liv. ${ }^{\circ}$ 183, fl. 159 v. ${ }^{\circ}$, doc. 311 (1407. XI. 24).

$\left({ }^{21}\right)$ Id., ibidem. Dourados, 3, fls. 130 v. ${ }^{\circ}-131$, n. ${ }^{\circ} 258$.

${ }^{(2)}$ Id., Chanc. D. $A f .^{\circ}$ V, 15, fl. 39 v. ${ }^{\circ}(1455$. V. 21$)$.

$\left.{ }^{(23}\right)$ JP Séc. XVII. pp. 283, 284-285, 288. 
um ou outro rendeiro de impostos) $\left({ }^{24}\right)$.

A hebreus ligados a Leiria se atribuíam os serviços de colecta de impostos, normalmente arrematados por eles em praça pública. Em 1378, um tal Freire de Leiria obtinha do rei carta para continuar a recolha da sisa dos dois soldos do vinho do almoxarifado de Óbidos, iniciada por seu irmão três anos antes, atingindo já então o montante de 6900 libras $\left({ }^{25}\right)$. Um tal Jardim arrendava os proventos das adegas alcobacenses em Aljubarrota, cuja soma atingia em 1410 a 1412 as 132000 libras $\left({ }^{26}\right)$. Em 1447, D. Belhamim Almeredim arrendava as sisas do Julgado de Alcobaça $\left({ }^{27}\right)$.

Lopo Vasques e Mestre Rodrigo, irmãos de judeus, arrendaram as sisas do almoxarifado de Leiria em 1445, ficando insolventes em pelo menos 9100 reais brancos $\left({ }^{28}\right)$. Também Abraão Pardal e Abraão de Baiona, rendeiros da Pederneira, se viram acusados de insolventes por 1490-91 $\left({ }^{29}\right)$. As grandes obras públicas atraíam igualmente o interesse judaico. Em 1495, aparece-nos Mousem Maçondra como rendeiro no almoxarifado das obras do Mosteiro da Batalha $\left({ }^{30}\right)$.

Para o período de 1401 a 1496, o quadro socio-proflssional dos judeus leirienses apresenta uma grande heterogeneidade de ofícios. No entanto, aparecem alguns de maior peso económico e social. Antes de todos surgem os mercadores (13 registos), seguidos por alfaiates (11 nomes) e por sapateiros (10 indivíduos). Vinham depois os ferreiros (6 nomes), os rendeiros de impostos ( 5 registos), os cirurgiões e ourives (4 para cada), físicos e tabeliães ( 3 para cada), depois os tipógrafos e os tintureiros (2

${ }^{(24}$ Sobre vias terrestres na região vide Iria Gonçalves, $O$ Património do Mosteiro de Alcobaça... cit., pp. 380-386.

${ }^{(25)}$ ANTT - Chanc. de D. Fernando. 4, fl. 28 (1378.10.17).

$\left.{ }^{(26}\right)$ ANTT - Alcobaça. $2 .^{a}$ inc., m. ${ }^{\circ} 30$, n. ${ }^{\circ} 765$ (26) (1410.IX.3).

${ }^{(27)}$ Id., ibidem, $2 .^{\mathrm{a}}$ inc., $\mathrm{m} .{ }^{\circ} 89$, doc. não numerado (1448.VII.5).

${ }^{(28)}$ Id., Batalha, 4, n. ${ }^{\circ} 109$ (1446.II.20).

${ }^{(29)}$ Id., Chanc. D. João II, 9, fl. 17 (1491.I.14).

$\left.{ }^{(30}\right)$ Id.. Batalha, $4, n \cdot{ }^{\circ} 33$. 
de cada). Sucediam-lhes inúmeros outros profissionais, conforme se poderá entrever no quadro junto.

\begin{tabular}{|c|c|c|c|c|}
\hline \multicolumn{5}{|c|}{$\begin{array}{c}\text { Quadro I-Amostragem socio-profissional dos judeus de Leiria } \\
\text { nos séculos XIII a XV }\end{array}$} \\
\hline Profissão & Séc. XIII & Séc. XIV & Séc. XV & Totais \\
\hline Mercador & & - & 13 & 13 \\
\hline Alfaiate & - & - & 11 & 11 \\
\hline Sapateiro & & & 10 & 10 \\
\hline Ferreiro & 1 & 2 & 6 & 9 \\
\hline Rendeiros & 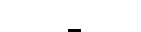 & 2 & 5 & 7 \\
\hline Proprietários & & & & \\
\hline rústicos & 1 & 4 & 1 & 6 \\
\hline Cirurgião & - & - & 4 & 4 \\
\hline Físico & - & 1 & 3 & 4 \\
\hline Físico e & & & & \\
\hline Cirurgião & - & - & 1 & 1 \\
\hline Ourives & - & - & 4 & 4 \\
\hline Tabelião & _ & _ & 3 & 3 \\
\hline Banqueiros & 1 & 1 & - & 2 \\
\hline Tipógrafos & & & 2 & 2 \\
\hline Criados & - & - & 2 & 2 \\
\hline Carniceiro & - & - & 1 & 1 \\
\hline Coiteiro & - & - & 1 & 1 \\
\hline Latoeiro & - & - & 1 & 1 \\
\hline Peliteiro & - & & 1 & 1 \\
\hline Tecedeira & _ & - & 1 & 1 \\
\hline Tecelão & - & - & 1 & 1 \\
\hline Tintureiro & - & - & 2 & 2 \\
\hline Trovador & 1 & - & - & 1 \\
\hline Sem identi- & & & & \\
\hline ficação & 6 & 4 & 45 & 55 \\
\hline
\end{tabular}


Pouco sabemos sobre os salários pagos aos mesteirais $\left({ }^{31}\right)$. Entre Agosto de 1437 e Janeiro de 1438,os alfaiates Salomão, Santo e Josepe entregaram obra feita ao Mosteiro de Alcobaça pela qual receberam 217, 226 e 20 reais respectivamente $\left.{ }^{(32}\right)$.

Dentro duma sociedade extremamente endogâmica, como a judaica, torna-se natural que os laços familiares se estendam a diferentes núcleos urbanos do território português, implicando nisso, como sugere Giacomo Todeschini $\left({ }^{33}\right)$, uma teia vivificante de actividades económicas. Entre os centros de fixação de judeus ligados a Leiria destacava-se, desde cedo, Lisboa $\left({ }^{34}\right)$, mas também Torres Vedras $\left({ }^{34 a}\right)$, Évora $\left({ }^{35}\right)$, Guarda $\left({ }^{36}\right)$,

$\left.{ }^{3}\right) J P$ Séc. $X V$, pp. 300-307.

$\left.{ }^{(32}\right)$ ANTT-Alcobaça, Liv. ${ }^{\circ}$ 14, fl. 126 v. ${ }^{\circ}$; id., ibidem, $2 .^{a}$ inc., m. ${ }^{\circ} 91$, não numerado.

(33) Cf. Giacomo Todeschini, "Familles juives et chrétiennes en Italie à la fin du Moyen Âge: deux modèles de développement économique", in Annales E.S.C., 45. année,n. ${ }^{\circ}$, pp. $787-818$.

${ }^{(3)}$ ANTT - Chanc. D. Afonso IV, 3, fl. $11 \mathrm{v} .^{\circ}(1327)$.

$\left.{ }^{(34 a}\right)$ E muito interessante, neste conspecto migracional dos judeus leirienses, o caso de Samuel de Leiria, escrivão, que nos surge entre as testemunhas dum acto notarial lavrado em Torres Vedras, em 26.III. 1283. O mesmo, ou um seu homónimo, aparecerá na mesma vila, como parte contratante, em diploma notarial de 5.XI. 1301. Não é seguro, no entanto, que este Samuel de Leiria fosse o escrivão da comuna torreense, ou do rabi-morou, sequer, da comunade Leiria (ANTT-Mosteiro de Alcobaça, 1. ${ }^{\mathrm{a}}$ incorp., $\mathrm{m} .{ }^{\circ} \mathbf{1 7}$, n. ${ }^{\circ} 6$ e m. ${ }^{\circ} 22$, n. ${ }^{\circ} 8$, respectivamente).

${ }^{\left({ }^{35}\right)}$ Arquivo Distrital de Évora-Pergaminhos dos Bacharéis, 1382-15/4; JP Séc. XVII, p.75. ANTT-Chanc. D. Duarte, 1, fl. 200 v. ${ }^{\circ}$; id., Odiana, VI, fl. 189 (1435.XII.23);

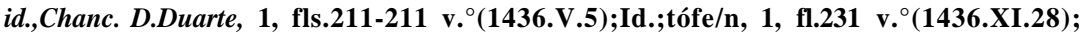
id. Chanc. $D$. $A f .{ }^{\circ} V$, 27. fl. 156 (1444); 3, fl. 66-66v. ${ }^{\circ}$ (1453). Arquivo da Misericórdia de Évora, n. ${ }^{\circ} 63$, fl. 29 (1458.XII. 19). ANTT - Chanc. D. $A f^{o} V$, 36, fls. 27-27 v. ${ }^{\circ}$; id., Odiana, V, fls. 290-290 v. ${ }^{\circ}(1459 . I I .4) ; D . A f^{o} V$, 29, fl. 27 v. ${ }^{\circ}(1472 . I V .9) ; ~ 33$, fls. 116 v. ${ }^{\circ}$-117; Odiana, IV, 155 v. ${ }^{\circ}-156$ v. ${ }^{\circ}(1473)$. Arq. Distrital de Évora-Cabido da Sé, Cód. CEC-6- VIII, fl. 9( 1473), fls. 151 v, ${ }^{\circ}-152$ ( 1475-1497); ANTT-Fundo Antigo, pasta 186, $n^{\circ} 3$ (1475-76). Iria Gonçalves, $O$ Empréstimo concedido a $D$. Afonso $V$, nos anos de 1475 e 1476, pelo almoxarifado de Évora, Lisboa, Direcção-Geral das Contribuições e Impostos,

1964. pp. 75-76. Arq. da Misericordia de Évora, n. ${ }^{\circ}$ 63, fls. 47-48 (1478).

(') A. Braamcamp Freire, "Tombo da Comarca da Beira", in Archivo Historico Portuguez, X.Lisboa, 1916, pp. 317-319. ANTT-Chanc. de D. Duarte, l, fls. 163(1435.XI.17), 173-173 v. ${ }^{\circ}$ (1435.XI.20), 172 v. $^{\circ}-173$ (1435.XI.27), 173 v. ${ }^{\circ}$ (1437.I.30); id., Chanc. $D A f .^{\circ} V$ 2, fls. $56 \mathrm{v}^{\circ}-59 \mathrm{v}^{\circ}(1441), 38$, fls. $96-96 \mathrm{v} .^{\circ}(1455), 15$, fls. 159-159 v. ${ }^{\circ}$ (1455) 
Santarém $\left({ }^{37}\right)$, Tomar $\left({ }^{38}\right)$, Viseu $\left({ }^{39}\right)$, Lamego $\left({ }^{40}\right)$, Portel $\left({ }^{41}\right)$, Trancoso $\left({ }^{42}\right)$ e Beja $\left({ }^{43}\right)$.

Quando não estamos perante cidades ou centros de grande actividade comercial e em expansão económica (v.g. Lisboa, Évora, Santarém), ficamos junto de centros fronteiriços com Castela (v.g. Guarda, Trancoso, Portel, Beja) em torno dos quais se desenvolviam importantes negócios de gados e de lanifícios. Mesmo que se tratasse dum centro já em relativa retracção económica, como era o caso da Guarda $\left({ }^{44}\right)$.

Para judeus de Leiria oriundos doutros centros apenas podemos apontar as povoações de Viseu, Abrantes e Bragança $\left({ }^{45}\right)$. É provável que as poderosas famílias lisboetas dos Faiam e dos Sassam tenham aqui familiares $\left({ }^{45 a}\right)$.

O comércio por todo o reino era praticado pelos judeus leirienses que para tal obtinham autorização régia. A sua importância pode atestar-se bem com o exemplo do mercador Jacob Baruc, ligado à casa do arcebispo de Braga, que conseguiu esse privilégio em $1441\left({ }^{46}\right), 1442\left({ }^{47}\right)$ e ainda em $1471\left({ }^{48}\right)$. Cremos que seria esta a razão principal que justificava a dispersão dos hebreus de Leiria por aquelas terras, mais do que um hipotético, e irreal, atrofiamento económico deste concelho e região que pro-

$\left.{ }^{(3)}\right)$ ANTT-Chanc. de D. Duarte. 1. fl. 134 (1437.IV.6); id., Chanc. de D.Af. ${ }^{o}$ V, 25, fl.74(1443.X.23). 11. fl. 117 (1451.VIII.4).

$\left(^{38}\right)$ ANTT- Chanc. D. Af. ${ }^{\circ} V .23$. fls. $68-v .^{\circ}, 83$ v. $.^{\circ}, 88,95$ v. ${ }^{\circ}, 104-104$ v. $.^{\circ}, 106$ v. ${ }^{\circ}-$ $-107(1441)$.

${ }^{(39}$ ANTT - Chanc. D. Af. $V$, 2. fls. 60-60 v. ${ }^{\circ}(1442)$.

$\left({ }^{40}\right)$ Id., ibidem. 15, fls. 159-159 v. ${ }^{\circ}(1455 . X I I)$.

( $\left.{ }^{41}\right)$ Id., ibidem. 6. fl. 20 (1476.I.26).

${ }^{\left({ }^{4}\right)}$ Id. ibidem. 31. fl. 25 v. ${ }^{\circ}(1469$. VI.21).

${ }^{\left({ }^{43}\right)}$ ANTT - Chanc. D. Af. ${ }^{o}$ V. 6. fl. 71 (1476.I.22).

(")JP Séc. $X V$, pp. 69-70. 314-325.

$\left({ }^{45}\right)$ Saul António Gomes, "A Antroponímia Judaica de Leiria Medieval (Subsídio para o seu conhecimento)", in História\& Crítica. n. ${ }^{\circ}$ 13. Lisboa, 1986, pp. 53-58. ANTT -Alcobaça. Dourados. 3, fls. 130 v. ${ }^{\circ}-131$. n. ${ }^{\circ} 258$.

${ }^{\left({ }^{s a n}\right)} J P$ Séc. $X V, p .232$.

$\left({ }^{46}\right)$ ANTT - Chanc. D. Af. $.^{o} \mathrm{~V}, 2$. fl. 76 v. ${ }^{\circ}$ (1441 .X.2).

$\left({ }^{47}\right)$ Id. ibidem. 24, fl. 44 (1443.XI.5).

$\left({ }^{48}\right)$ Id., ibidem, 16. fl. 50 (1471.II.8). 
vocaria esses surtos emigratórios. Que assim não era prova-o o próprio crescimento das unidades comunais em torno de Leiria, motivado pela dinâmica dos seus mercados financeiros e de trabalho. Não se trata, pois, duma situação de empobrecimento, sendo antes expansiva. Deste modo, e nesta leitura, a proliferação migratória por aquelas cidades e vilas denunciará interesses estruturais dentro da comunidade judaica, nomeadamente o da extensão geográfica das redes de solidariedades familiares sanguíneas e afins.

As capacidades económicas da comuna leiriense tornaram-se evidentes desde finais de Trezentos. D. Fernando, por exemplo, ao doar os direitos de Leiria a Aires Gomes da Silva reserva para si as rendas da judiaria $\left({ }^{49}\right)$. D. João I legisla com a maior atenção sobre a obrigatoriedade de os mercadores judeus do almoxarifado serem inscritos no rol para pagamento ou isenção dos serviços real e novo $\left({ }^{50}\right)$.

O serviço real da judiaria rendia 20000 reais em $1441\left(^{51}\right)$ e ainda em $1460\left({ }^{52}\right)$. Em 1463, contudo, o mesmo serviço é equiparado a 30000 reais $\left({ }^{53}\right)$, assim se mantendo em $1467\left({ }^{54}\right)$ e, porventura, em $1473\left({ }^{55}\right)$.

Contudo, na avaliação feita em 1501, para compensação do marquês de Vila Real, D. Fernando de Meneses, privado dessas rendas em consequência da expulsão de fins de 1496, o serviço real da comuna de Leiria era estimado em 24471,66 reais por ano $\left({ }^{56}\right)$. A judiaria de Ourém rendia, na mesma altura, 5790 reais $\left({ }^{57}\right)$, sensivelmente $1 / 4$ da de Leiria. A comuna de Porto de Mós ficava-se pelos 2820 reais, em $1498\left(^{58}\right)$. Em

(") Id., Chanc. D. Fernando, 1, fl. 119 (1373.IV.12).

$\left(^{50}\right)$ Id. Chanc. D. João I, 5, fl. 73 (1410.V.30).

( $\left.{ }^{51}\right)$ Id., Chanc. D. Af. ${ }^{o} V$, 2, fl. 102 (1441.IV.2).

$\left(^{(52)}\right.$ Id., ibidem, 36, fl. 228 (1460.1.29).

$\left(^{(5)}\right)$ Id., ibidem, 9, fl. 103 v. ${ }^{\circ}(1463$. V.21).

$\left(^{54}\right)$ Id. ibidem, 33, fls. 148-148 v. ${ }^{\circ}$ (1467.I.27).

${ }^{\left({ }^{5}\right)}$ Jorge Faro, Receitas e Despesas da Fazenda Real de 1384 a 1481, Lisboa, ed. Centro de Estudos Económicos, 1965, pp. 175-176, 186.

$\left(^{56}\right)$ ANTT-Místicos, I, fls. 276 v. ${ }^{\circ}-277$ v. ${ }^{\circ}(1501 . X I I .10)$.

( $\left.{ }^{57}\right)$ Id., ibidem, I, fls. 279 v. ${ }^{\circ}-280$ (1501.XII.6).

${ }^{(58)}$ Id., Chanc. de D. Manuel, 31, fl. 70 v. ${ }^{\circ}(1498)$. 
1500, no entanto, seria avaliada em 1000 reais, enquanto Ourém renderia 6000 reais $\left({ }^{59}\right)$. A documentação não explica as razões destas diferentes avaliações.

A judiaria leiriense pagava também a peita ferreira, para custeamento de despesas com Ceuta, atingindo 1081 reais em $1452\left({ }^{60}\right)$. Este imposto não era idêntico ano após ano. De facto, as comunas de Leiria, Abrantes, Alenquer, Santarém e Torras Novas pagavam, no conjunto, 4749 reais, em 1451 e 3649 reais em $1453\left({ }^{61}\right)$. Os seus índices não permitem, por isso, estabelecer hierarquias na importância das comunas judaicas referidas.

Em 1483-84, as comunas de Coimbra, Leiria e Trás-os-Montes emprestavam ao monarca 243500 reais, soma considerável, mas que nada esclarece sobre o peso da judiaria em estudo naquela soma $\left({ }^{62}\right)$.

Fonte de riqueza, tornava-se fácil ao rei premiar os seus servidores com os rendimentos dela oriundos, ou então entregar a sua administração a indivíduos credores de mercês da coroa. Por isso, D. João I doará o sisão da comuna de Leiria a Álvaro Vasques, capitão, por $1431\left({ }^{62 a}\right)$,e D. Duarte, logo no começo do seu reinado, as rendas do serviço real da comuna de Leiria a Mestre Guedelha, o que lhe será confirmado pelo regente D. Pedro, em 1439, e por D. Afonso V em $1449\left({ }^{63}\right)$.

Em 1460,essas rendas são doadas a Vasco Martins Chichorro, fidalgo da casa real e capitão dos ginetes $\left({ }^{64}\right)$. Três anos depois ser-lhe-ia aumentada a tença, por seu casamento, passando de 20 mil para 30 mil reais $\left({ }^{65}\right)$. Por contrato entre este beneficiário e D. Fernando de Meneses, conde de Vila Real, de 1467, essas rendas passam a ser usufruídas por este $\left({ }^{66}\right)$.

$\left(^{59}\right)$ Id., Místicos. II. fls. 269-270 (1500.XII.15).

${ }^{\left({ }^{60}\right)}$ Id., Chanc. D. Af. ${ }^{o}$ V. 15, fls. 172 v. ${ }^{\circ}-173$ (1455.VIII.15).

( $\left.{ }^{61}\right)$ Id., ibidem.

$\left({ }^{62}\right)$ Id., Odiana. II. fls. 109-110 v. ${ }^{\circ}(1484 . I V . I)$.

$\left.{ }^{(2 a}\right)$ Id., Chanc. D. Af..$^{o}$ V. 34. fl. 153; JP Séc. XVII. p. 730.

${ }^{\left({ }^{3}\right)}$ Id., ibidem. 18. fl. 30 v. ${ }^{\circ}(1439 . V .20)$; 34. fl. 116 (1449.XII.16).

$\left(^{64}\right)$ Id., ibidem. 36. fl. 228 (1460.I.29).

(65) Id., ibidem. 9. fl. 103 v. ${ }^{\circ}(1461 . V .21)$.

${ }^{\left({ }^{6}\right)}$ Id., ibidem. 33. fls. 148-148 v. ${ }^{\circ}$ (1467.I.27). 
Antes de 1473, as rendas da judiaria, no valor de 30000 reais, e as do serviço real, no montante de 20000 reais, devem ter sido recolhidas, ou administradas, por Álvaro Barreto e Álvaro de Brito, respectivamente $\left({ }^{67}\right)$. Devemos estar perante homens beneficiados porventura pelo conde de Vila Real, que nunca perdeu essas rendas até 1496 ( ${ }^{6}{ }^{8}$ ) .

O judiciado das sisas dos judeus de Leiria andou em posse de Lucas Eanes, aristocrata local, desde o reinado de D. João I, até 1466, altura em que é dado a Luís Lopes, escudeiro do duque de Bragança, residente em Leiria $\left({ }^{(6)}\right.$. A escrivaninha dos serviços real e novo era trazida em regime de acumulação com outros ofícios, por Luís Vicente, já desde antes da morte de D. João I $\left({ }^{70}\right)$. Passou a Pedro Álvares Varela, antes de 1455, e, nesta data, a Gonçalo Eanes, escrivão do almoxarifado e ex-guarda de D. Jaime, cardeal $\left({ }^{11}\right)$.

É de sublinhar o cuidado régio em entregar as responsabilidades administrativas dos serviços real e novo de Leiria a oficiais já previamente ligados aos problemas correntes do almoxarifado. Se isso poderá indicar a preocupação centralizadora da coroa, por um lado, é igualmente lícito afirmar que, sem prejuízo desse interesse, conseguia-se, por outro modo, satisfazer as pressões e solicitações duma clientela de oficiais apaniguados das casas nobiliárquicas mais intimamente ligadas à nova dinastia de Avis.

Neste contexto, a minoria judaica contribuía para a continuidade das estruturas económico-administrativas da coroa portuguesa, inserindo-se

(") Jorge Faro. op. cit., pp. 175-176.186.

${ }^{\left({ }^{65}\right)}$ ANTT-Místicos. II. fls. 65-66; pub. por Manuel Heleno, Antiguidades de Monte Real, Lisboa, ed. Imprensa Nacional. 1922. pp. 49-53; ANTT - Místicos, I, fls. 276 v. ${ }^{\circ}$ -277 (1501.XI1.I0).

$\left(^{(9)}\right.$ ANTT-Chanc. Af. ${ }^{\circ}$ V, 18. fl. 107 v. ${ }^{\circ}(1433 . X I I .7$ e 1439.VI.18); id., Alcobaça, 2. ${ }^{\mathrm{a}}$ inc, m. ${ }^{\circ} 62$. n. ${ }^{\circ} 20$ (1453.VI.1); id., Chanc. D. Af. ${ }^{\circ}$, 14 , fl. 110 v. ${ }^{\circ}(1466 . V .3)$.

$\left(^{70}\right.$ ANTT - Chanc. D. Af. ${ }^{\circ} V$. 19, fl. 24 v. ${ }^{\circ}(1439 . V .1)$. Era também escrivão do almoxarifado de Leiria, do relego e das obras da Batalha. Ver Saul António Gomes, $O$ Mosteiro de St. ${ }^{a}$ Maria da Vitória no Século XV. Coimbra, ed. Instituto de História da Arte, Faculdade de Letras de Coimbra, pp. 77-81.

( ${ }^{\prime)}$ ANTT - Chanc. D.Af. ${ }^{o}$ V. 15, fl 115 (1455.XI.3). 
num complexo conjunto de actividades tributárias que sustentavam a sociedade política nacional no seu todo.

\section{Sociedade e vida quotidiana.}

Comunidade local relativamente reduzida e endogâmica, encontramos nela, no entanto, uma grande diversidade de comportamentos individualizantes. É justamente por isso que devemos distinguir à partida de qualquer análise entre os privilegiados eos não privilegiados ( $\left.{ }^{1}\right)$. Por detrás desta separação encontram-se factores económicos fundamentalmente. O privilegiado é necessariamente rico, indivíduo de sucesso profissional que vê reconhecidos os seus méritos pelo rei e pelo restante corpo social.

$O$ rei privilegiava individualmente ao conceder isenções fiscais e mercês autorizando o livre trato por todo o País. Efectivamente, eram privilégios de foro económico-mercantil aqueles que mais se procuravam. Daqui, a razão justificadora de inúmeras cartas outorgadas pelo monarca para se poder comerciar com iguais direitos aos cristãos e, tal como a estes, para se poder utilizar animais de tiro e de sela nas deslocações $\left({ }^{2}\right)$.

Os privilégios incidiam também sobre as responsabilidade do indivíduo face à comunidade judaica. Assim, isentava-se de participação em encargos comuns, serviços à comuna, impostos concelhios e obrigação de aposentadoria $\left({ }^{3}\right)$.

A físicos e cirurgiões, por pedido do concelho, concedia-se normalmente o direito de habitar na "cristandade" $\left({ }^{4}\right)$.

(') JP Séc. $X V$. pp. 215-216.

(') JP Séc. $X V$. pp. 174-179 e Quadro 9. ANTT - Chanc. D. Af. ${ }^{o}$ V. 35, fl. 53

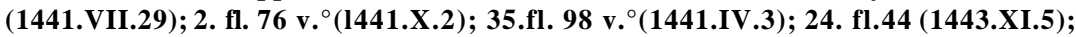
15, fl. 158 (1455.X.15); 28. fl. 3 v. ${ }^{\circ}(1468 . .18) ; 28$. fl. 86 v. ${ }^{\circ}(1468 . I X .22) ; 29$, fl. 81 (1471.I.8); 16,fl.50(1471.n.8); 16. fl.57 (1471.III.15); 16, fl. 141 v. ${ }^{\circ}(1471 . I I I .22) ; 33$, fl. 29 v. ${ }^{\circ}(1472 . X I I .13) ; 33$. fl. 211 v. ${ }^{\circ}(1473 . X I I .6)$.

() Ibidem.

(')JP Séc. XV-II. Quadron ${ }^{\circ}$. ANTT - Chanc. D. Af. ${ }^{\circ}$ V, 15. fl. 62 v. ${ }^{\circ}(1455 . V I I .10)$; 15, fl. 62 v. ${ }^{\circ}\left(1455\right.$. VII.10); 16, fl. 4 v. ${ }^{\circ}$ (1471.I.14); 21, fl. 87 (1471.I.16). 
Em 1452, a comuna agravava-se perante o rei, denunciando a dificuldade no levantamento de pedidos e serviços, porquanto "muytos judeus sse escussam de pagarem elles per cartas E priujllegios" ( $\left.{ }^{5}\right)$. A situação era provavelmente de ruptura, levando $D$. Afonso $V$ a suspender os privilégios já concedidos de isenções de encargos comunais, autorizando mesmo os "oficiaees $\mathbf{E}$ homeens boons delia (que) possam poer de ferros e escumunhõees e penas $\mathbf{E}$ fazer todallas outras hordenaçõees que entenderem que sejom fectas per hordem de sua ley que per outra qualquer gujssa per que nehuu Judeu se nom escuse daqui en diante nem gaanhe carta nem priujllegio per que nom pague em as coussas sobredictas" ( $\left.{ }^{6}\right)$.

Apesar dessa carta, o rei voltará a conceder privilégios individuais nos anos seguintes, como fez com José Praieiro, ex-ourives da imperatriz D. Leonor $\left({ }^{7}\right)$, e com Salomão Almerdam, ourives $\left({ }^{8}\right)$, ou ainda com Moisés Levi ('), no ano de 1469.

A repartição dos impostos, sobretudo aquando do lançamento de pedidos ou de empréstimos, caía de forma desigual sobre os habitantes da aljama. Em 1490, David ben Mentos queixava-se de que "auja quorenta annos que vyuja em a decta Villa e sempre pagara e peytara tanto e mais que cada hü dos judeus seus jguaees que em ella Viuem e que por alguem dos judeus da decta Villa lhe querer mall e lhe com hodeo lhe lançaram ora neste emprestado que ora lançamos a comuna da decta villa de cynquoenta mjll rreais que nos emprestasem a Vemdo em Veja de seu boom Viuer lhe deytaram em ho decto emprestado que pagase tanto e mais que ho mais rrico que em a decta ujlla avia", o que era tido por grande mau trato da comuna para com ele $\left({ }^{10}\right)$.

\footnotetext{
(') A N T T - Chanc. D. Af..$^{o}$ V, 3. fls. 58-58 v. ${ }^{\circ}$ (1452.XII.3).

( $\left.{ }^{6}\right)$ Ibidem.

(') Id., ibidem 31. fl. 54 (1469.VI. 15).

$\left.{ }^{8}\right)$ Id., ibidem. 31. fl. 54 (1469.VI. 17).

(') Id., ibidem. 31. fl. 59 (1469.VII.5).

$\left({ }^{10}\right)$ Id., Chanc. D. João II. 16, fl. 39 v. ${ }^{\circ}$ (1490.IV.25).
} 
Inseridos numa sociedade cristã profundamente patriarcal, os hebreus parecem dar uma maior importância à mulher do que era normal entre cristãos. A isso obrigavam as próprias estruturas familiares dum grupo endogâmico por tradição histórica.

Na documentação por nós compulsada, no entanto, é muito raro aparecer-nos a mulher como protagonista de actos notariais ou judiciais. Excepção feita a uma tal D. Justa, que surge como marco referencial nalguns diplomas de finais de Duzentos e inícios da centúria seguinte. Esta mulher é apresentada, por exemplo, como sogra dum tal Abraão (" Abrãa genrro de dona justa", "abraham judeu... jenrro em outro tempo de dona justa judia" ("))• Situação similar é a que respeitava a uma D. Sol, tia de Moisés, casado com outra D. Sol, que houve todo o cuidado de indicar numa carta de renúncia feita por este em $1293\left({ }^{12}\right)$. Também em 1327, uma D. Judeia de Leiria, e seu filho, aforam do rei um sótão em Lisboa $\left({ }^{13}\right)$.

Estas afirmações da individualidade feminina, contudo, poderão derivar fundamentalmente do estatuto económico de riqueza das mesmas e do seu protagonismo na administração dessa dita fortuna.

Na sociedade medieval local, considerava-se que, após os dez anos de idade, as moças cristãs já não deveriam entrar sozinhas na judiaria $\left({ }^{14}\right)$. $O$ estatuto de mulher começava, pois, muito cedo. Mesmo para as judias. Um tal Yada, de 15 anos, "per emgalho e emdizimento de huua judia manceba", sua prima, rouba 12000 reais a seu pai, fugindo com a dita judia em $1486\left({ }^{15}\right)$. Clarina, órfã de mestre Belhamim, tinha $24(\mathrm{XX})$ reais para o seu casamento em 1483, que lhe acabariam por ser sonegados, segundo testemunho de Fernão Rodrigues Danta, tabelião das notas e escrivão dos feitos das sisas em Leiria, pelo rabi da comuna, Favame ${ }^{\left({ }^{16}\right)}$.

( $\left.{ }^{1 ~}{ }^{\prime}\right)$ ANTT-Alcobaça, $1 .^{\text {a }}$ inc, m. ${ }^{\circ}$ 9. n..$^{\circ} 24$ (1292.IV.25); Bib. Nacional de Lisboa -Reservados: Cód. 736. fls. 260-261 (1306.VI.30).

(') ANTT-Alcobaça. $1 .^{\mathrm{a}}$ inc. m. ${ }^{\circ}$ 19. n. 37 (1293.IV. 17).

$\left(^{(3)}\right.$ Id., Chanc. de D. Afonso IV, 3. fl. 11 v. ${ }^{\circ}(1327 . X .7)$.

(') Id., Chanc. D. Af. ${ }^{o} V$ 15, fls. 57-58 (1455.VI.26).

(') Id., Chanc. D. João II. 1, fl. 30 (1486.II.15).

( ${ }^{16}$ ) Id., Chanc. D. João II. 14, fls. 6-7 (I483.VIII. 18). 
Os costumes e leis judaicas eram seguramente observados na comuna. A começar pela vigilância exercida pelos rabis. É o rabi que põe penas, multas e degredos, obviando a pacificação entre famílias, em $1475\left(^{(17}\right)$. Ao rabi competia também fazer respeitar o Sábado $\left({ }^{18}\right)$. Este chefe da comunidade era eleito, muito embora se exigisse uma formação cultural cuidada por quem desempenhava tal missão $\left({ }^{19}\right)$.

Em Leiria, contudo, estudava-se a nível superior a teologia mosaica. Por 1481, residiam na comuna alfaquis, ou seja, doutores da Lei $\left({ }^{20}\right)$. Esta presença pode ser bastante longínqua se tivermos em atenção que se cobrava genesim na cidade já por $1394\left({ }^{21}\right)$. De qualquer modo, prova que a comunidade local dava uma grande atenção ao conhecimento dos preceitos vetero-testamentários e ao seu ensino.

É esta vertente cultural que explicará, ao menos em parte, a capacidade da comunidade judia em formar físicos e cirurgiões verdadeiramente aptos na medicina. Efectivamente, os seus serviços eram constantemente reclamados pela comunidade cristã. Leiria é bom exemplo.

O primeiro físico em Leiria, que saibamos, foi Mestre Juda, que aqui residiu antes de $1334\left({ }^{22}\right)$. Também Mestre Moisés, rabi-mor e físico de D. João I, aqui tinha interesses em prédios urbanos $\left({ }^{23}\right)$. Já em 1440, encontramos Mestre Belhamim, cirurgião, a exercer o seu ofício na cidade. Será ele, aliás, que afora casas do Mosteiro da Batalha em 1449

(") Id.. Chanc. $D$. $A f .^{\circ} V$, 30, fl. 128 v..$^{\circ}(1475 . I V .17)$. Entre os rabis da comunidade leiriense citam-se os seguintes:

- 1293: rabi Isaac (ANTT-Alcobaça, $1 .^{\mathrm{a}}$ inc, m. ${ }^{\circ}$ 19. n. $\left.{ }^{\circ} 37\right)$.

- 1472: rabi Moisés (ANTT - Chanc. D. Af..$^{\circ}$ V. 29, fl. 248 v. ${ }^{\circ}$ ).

- ca. 1482: rabi Favame (ANTT-Chanc. D. João II, 14, fls. 6-7).

$\left.{ }^{18}\right)$ ANTT - Chanc. D. Af. ${ }^{o}$ V, 36. fl. 118 (1459.VI.6).

$\left({ }^{19}\right)$ Id., ibidem, 31. fl. 59 (1469.VII.5).

$\left(^{20}\right)$ Id., Chanc. D. Manuel. 43. fl. 34 (1496.IV.29). Sobre os alfaquis vide Fr. João de Sousa, Vestígios da Língua Arábica em Portugal (ed. de Farinha de Carvalho), Lisboa, 1981. p. 30. s. v. "alfaqui".

${ }^{2 l}$ ) ANTT-Alcobaça. 1. ${ }^{a}$ inc., $m .{ }^{\circ} 19$, n. ${ }^{\circ} 46$ (1394.VI.3).

$\left(^{2}\right)$ ANTT-Alcobaça. $1 .^{a}$ inc., $\mathrm{m} .{ }^{\circ} 30, \mathrm{n}^{\circ} 9$ (1344.III.9).

$\left(^{23}\right)$ ANTT - Estremadura, XI. fls. 67-67 v. ${ }^{\circ}$; id., Chanc. D. João I, 2, fl. 62 v. (1391.XII.6). 
e que, em 1455, com o estatuto de cirurgião e físico, é autorizado a viver na "cristandade", a pedido do concelho leiriense. Terá falecido pouco antes de 1483, exercendo, pois, o seu ofício ao longo de pouco mais de quarenta anos $\left({ }^{24}\right)$.

Outro cirurgião aqui residente era Mestre Abraão, privilegiado já em 1438 e ainda em 1441 e $1443\left({ }^{25}\right)$.Em 1446, foi passada carta de cirurgião a outro Mestre Abraão ${ }^{\left({ }^{26}\right)}$. Encontramos ainda, em Leiria, Mestre Efraim, físico (1470) $\left.{ }^{(27}\right)$, Mestre Juda ben Atar. cirurgião (1471) $\left({ }^{28}\right)$, Mestre Abraão Abeatar, cirurgião e físico (1471) $\left({ }^{29}\right)$, rabi Mestre Moisés Latam, físico (1472) $\left.{ }^{(30}\right)$ e Mestre Samuel de Alva, físico (1482) $\left({ }^{31}\right)$. Também na comunidade vizinha da Pederneira havia cirurgiões, casos de Mestre Lembroso Ben Azo e de seu filho Mestre José (1491) $\left(^{32}\right)$.

Os serviços especializados destes judeus interessavam bastante aos cristãos, razão por que o concelho de Leiria, em 1471, requeria que Mestre Abraão Abeatar tivesse porta aberta para a "cristandade", o mesmo se aplicando a seu filho Judas ben latar $\left({ }^{33}\right)$.

Permaneceriam em Leiria após 1496. Encontramo-los com nomes cristãos, como Mestre Rodrigo, cirurgião. Mestre António, físico, e Mestre Gil de Leiria, cirurgião (1498-1499) $\left({ }^{34}\right)$.

Os cirurgiões leirienses, judeus ou não, eram suficientemente conhecidos para motivarem as atenções dos trovadores de finais de Duzentos. Época em que, aliás, a comuna conhecia os seus próprios poetas, como

$\left({ }^{24}\right)$ A N T T - Chanc. D. Af. ${ }^{\circ}$ V.34, fl. 116 (1449.XII. 16); 15, fl. 62 v. ${ }^{\circ}(1455$. VII.10); id., Batalha. 4. n. 155 (1449.VIII. 19); id., Chanc.D. João II. 14. fls. 6-7 (1483.VIII. 18).

$\left({ }^{25}\right)$ ANTT-Chanc. D.Af. ${ }^{\circ}$ V,15. fl. 35 (1441.VII.29); 27, fl. 105 v. ${ }^{\circ}(1443 . V I .12)$.

${ }^{\left({ }^{26}\right)}$ ANTT - Chanc. D. Af. ${ }^{o} V .5$, fl. 23 v. ${ }^{\circ}(1446.1 \mathrm{~V} .3)$.

$\left({ }^{27}\right)$ ANTT - Chanc. D. Af. ${ }^{\circ} V$, 21, fl. 87 (1471.I.16).

$\left({ }^{28}\right)$ Id., ibidem. 16, fl. 5 (1471.I.9).

$\left({ }^{29}\right)$ Id., ibidem 16, fl. 4 v. ${ }^{\circ}$ (1471.I.14).

${ }^{(30)}$ Id., ibidem. 29, fl. 248 v. ${ }^{\circ}$ (1472.XI. 18).

(') Id., Chanc. D. João II. 3, fl. 102 (1482.XII.24).

$\left({ }^{32}\right)$ Id., ibidem. 11, fls. 34-34 v. ${ }^{\circ}$ (1491.IX.1); 34, fl. 34 v. ${ }^{\circ}(1491 . I X .1)$.

$\left(^{33}\right)$ Id., Chanc. D. Af..$^{\circ}$ V. 16, fl. 4 v. ${ }^{\circ}(1471 . I .14) ; 21$, fl. 87 (1471.I.16).

$\left({ }^{34}\right)$ Id., Chanc. D. Manuel I. 31. fl. 139 v. ${ }^{\circ}(1498 . X .19)$; 12. fl. 12 (1499.I.2); 14, fl. 14 v. ${ }^{\circ}$ (1499.III.14). 
Samuel, trovador, aqui residente em $1293\left({ }^{35}\right)$.

De faeto, atribui-se a João Fernandes d'Ardeleiro uma cantiga de escarnho sobre os sangradores leirienses que bem se poderá interpretar como crítica implícita a um ofício tradicional dentro da comunidade judia $\left({ }^{36}\right)$.

Das poucas cartas de perdão encontradas, relativas a judeus desta cidade, a maior parte respeita a crimes de falsificação de documentos fiscais e processuais. Em 1456, Jacob Baruc, Bento Sassom, Isaque Levi e Belhamim, rendeiros das sisas de Leiria entre 1449 e 1451, foram perdoados da acusação de "talhamento" de folhas nos livros de registo dessas sisas $\left({ }^{37}\right)$. Moisés Tiboba seria acusado de falsificação no processo duma inquirição sobre Abraão Caro, sua mulher e Samuel Caro, por 1476, vindo a ser preso por isso $\left(^{38}\right)$.

Jonas Abeatar foi acusado de desobediência ao ouvidor da comuna, por 1471, em virtude de ter participado com "certos judeus huus com os outros (que) sse aleuantaram Em Razoees $\mathbf{E}$ em brados aos quaees elle mandara Da nossa parte que se fossem $\mathbf{E}$ ssendo (em) huua casa omde estauam pormemtemdo de Nunca Em nemhuu tempo por ello acusar nem de mamdar", o que ele não acatara $\left({ }^{39}\right)$.

Era também frequente o roubo. Juda, moço de 15 anos, rouba ao seu próprio pai doze mil reais( $\left(^{(*)}\right.$ Mesmo os judeus são alvo do roubo de cristãos. Judas, proprietário duma alcaceria em Porto de Mós, foi roubado por Pero Domingues Carvalho, que escondeu parte da coirama na

("s) Id., Alcobaça. 1. ${ }^{a}$ inc., m. ${ }^{\circ}$ 19, n. 37 ( 1293.IV. 17).

$\left(^{36}\right)$ Manuel Rodrigues Lapa. Cantigas de Escarnho e de Mal Dizer dos Cancioneiros Medievais Galego-Portugueses,.1., ed. Galáxica, 1965, n. ${ }^{\circ}$ 200. Cf. Mário Martins, A Sátira na Literatura Medieval Portuguesa (Séculos XIII e XIV), Lisboa, ed. I.C.P., col. "Biblioteca Breve", 1977. pp. 87-88.

${ }^{\left({ }^{37}\right) \text { A NT T-Chanc. D. } A f .^{o} V ., 13, \text { fl. } 51 \text { v. }{ }^{\circ}(1456 . V I I .8) .}$

$\left({ }^{38}\right)$ Id., ibidem, 6, fl. 71 (1476.XI.5).

${ }^{\left({ }^{3}\right)}$ Id., ibidem, 26, fls. 47 v. $^{\circ}$ - 48 (1481 .VIII.2).

$\left.{ }^{(10}\right)$ ANTT - Chanc. D. João II, 1, fl. 30 (1486.II.15). 
povoação vizinha de Aljubarrota $\left({ }^{41}\right)$.

Aspectos dum quotidiano refractário, é certo, mas que nos testemunham a presença judaica em Leiria como entidade promotora muito significativa da dinâmica económica regional ao longo da Idade Média.

SAUL ANTÓNIO GOMES

(') Id., Chanc. D. Af..$^{o}$, 15. fl. 39 v. ${ }^{o}(1455 . V .21)$. 